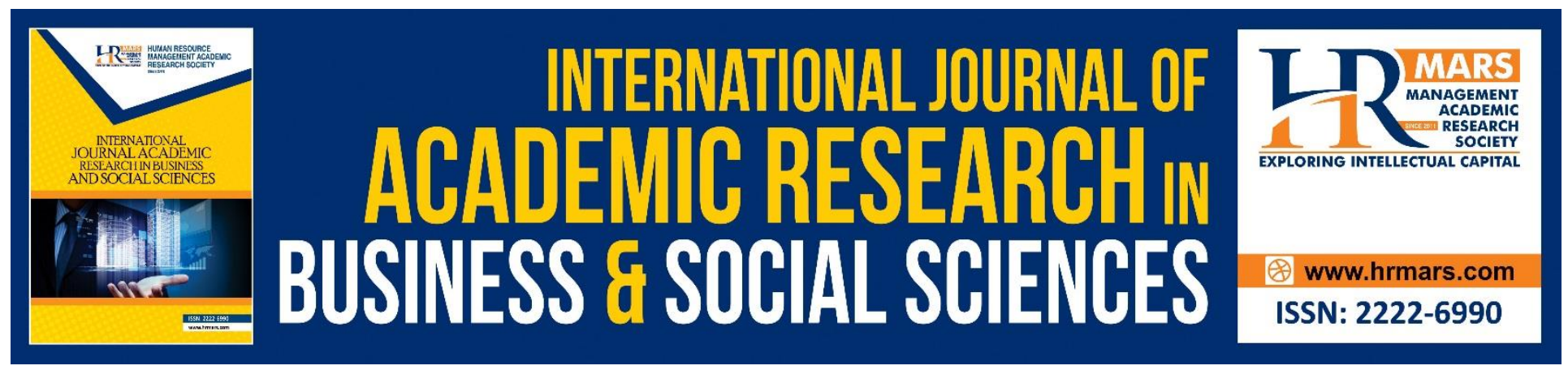

\title{
The Influence of Self-Directed Professional Learning in Enhancing Leadership Competency: A Concept Paper
}

Kho Chee Yuet Fanny, Mahaliza Mansor

To Link this Article: http://dx.doi.org/10.6007/IJARBSS/v9-i2/5616 DOI: $10.6007 /$ IJARBSS/v9-i2/5616

Received: 12 Jan 2019, Revised: 24 Feb 2019, Accepted: 10 March 2019

Published Online: 12 March 2019

In-Text Citation: (Fanny \& Mansor, 2019)

To Cite this Article: Fanny, K. C. Y., \& Mansor, M. (2019). The Influence of Self-Directed Professional Learning in Enhancing Leadership Competency: A Concept Paper. International Journal of Academic Research in Business and Social Sciences, 9(2), 795-803.

Copyright: (C) 2019 The Author(s)

Published by Human Resource Management Academic Research Society (www.hrmars.com)

This article is published under the Creative Commons Attribution (CC BY 4.0) license. Anyone may reproduce, distribute, translate and create derivative works of this article (for both commercial and non-commercial purposes), subject to full attribution to the original publication and authors. The full terms of this license may be seen at: http://creativecommons.org/licences/by/4.0/legalcode

Vol. 9, No. 2, 2019, Pg. 795 - 803

Full Terms \& Conditions of access and use can be found at http://hrmars.com/index.php/pages/detail/publication-ethics 


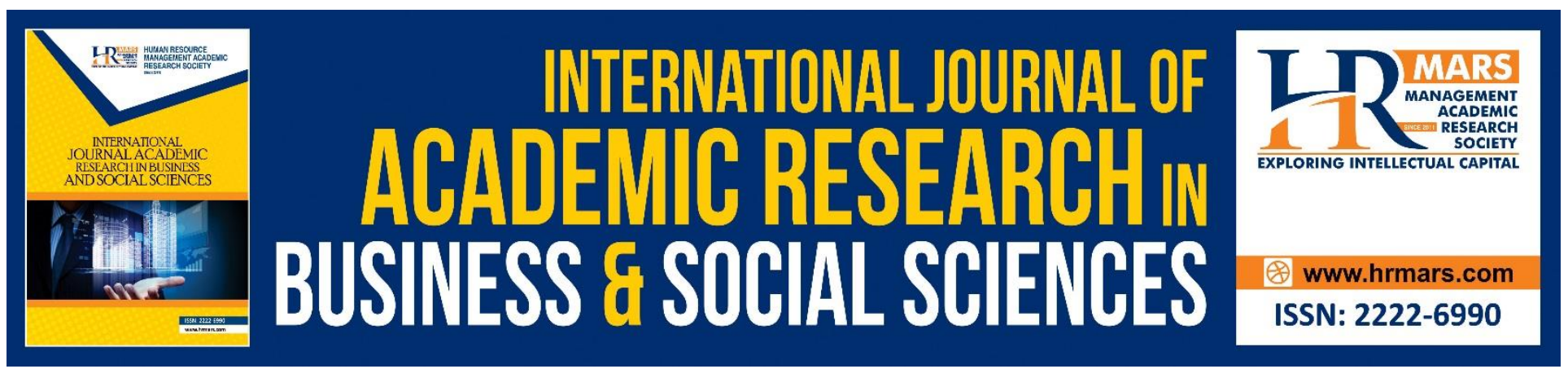

\title{
The Influence of Self-Directed Professional Learning in Enhancing Leadership Competency: A Concept Paper
}

\author{
Kho Chee Yuet Fanny, PhD
}

Faculty of Management and Economics, Sultan Idris Education University, Malaysia

\author{
Mahaliza Mansor, PhD
}

Faculty of Management and Economics, Sultan Idris Education University, Malaysia

\begin{abstract}
This study proposed to investigate the influence of teachers' self-directed professional learning in enhancing Teachers' Leadership Competency (TLC) through teachers' Action (ACT), Thinking (THI), Feeling (FEE), Accessing (ACC) in Facilitating Improvement and Establishing Standards (FIES), Modeling Leadership Attributes and Skills (MLAS), Participating in Organizational Development (POD), Fostering a Collaborative Culture (FCC), and Performing as Referral Leader (PRL) as well. The data will be collected from 301 teachers from 12 sample schools through self-administered of Teacher Learning and Competency Scale (TLCS) survey instrument. The samples will be selected through proportionate random sampling procedure. The collected data will be analyzed using SPSS software package. The pilot-test data will be analyzed utilizing Exploratory Factor Analysis (EFA). The Second Order Confirmatory Factor Analysis (CFA) or known as Pooled Measurement Model will be employed to assess the model fit of TL and TLC latent constructs. The Structural Equation Modeling (SEM) will be employed to analyze the final data. Theoretically, this study contributes to the literature on the influence of teachers' self-directed professional learning towards teachers' leadership competency in Malaysia.
\end{abstract}

Keywords: Teachers' Self-Directed Professional Learning, Teachers' Leadership Competency, Action, Thinking, Feeling, Accessing.

\section{Introduction}

As Malaysia steps forward in pursuit of its Vision 2020, the changing landscape of Malaysian schools require self-directed professional actions of teachers to take charge of their own professional development (Lieberman, Campbell \& Yashkina, 2017). This landscape is in line with the Ministry of Education (MOE) policies, the National Philosophy of Education (NPE), the Philosophy of Teacher 
Education (PTE), and the Malaysian Education Blueprint (MEB) 2013-2025 as well, whereby the emphasis is on life-long learning (KPM, 2012). Life-long learning in this study focuses on teachers' self-directed professional learning which can be in the form of training, individual coaching, and through on-the-job opportunities such as project and task team involvement (Timperley, Wilson, Barrar, \& Fung, 2007), which will ultimately result in a positive contribution to the change process in school improvement (DuFour \& Fullan, 2013).

Successful change process requires personalized set of learning opportunities (Marcus \& Pringle, 1995). Current trends revealed that enhancing leadership competencies is a valuable piece of teachers' self-directed professional learning (Yamazaki \& Kayes, 2004). Indeed, research on selfdirected learning has focused on the roles of teachers as leaders of instructional practices and pastoral support (Darling-Hammond, 1999; Hill \& Amabile, 1993; Crowther, 2002a \& 2002b). In an educational context characterized by complexity, diversity and pressure on teachers and students for improved academic and social outcomes, a model of self-directed learning opportunities focusing, primarily, on the principal is not desirable or sustainable. The challenge is to find ways of encouraging more teachers to enhance their leadership competencies (Kho, Hamidah Yusof \& Syed Ismail Syed Mohamad, 2015c).

Clearly, a new paradigm of teachers' self-directed professional learning is needed, one that recognizes both the capacity of the profession to provide new form of leadership community in schools (Crowther et al., 2002a; Kho, Hamidah Yusof \& Syed Ismail Syed Mohamad, 2016). In relation to this, teachers need to be equipped with sustainable leadership competencies, if not schools reform will fall short to provide equal access to quality education of an international standard, and to ensure every child develop values-driven Malaysian holistically. In this regard, teachers in schools with a collaborative culture relatively find that there are many opportunities to learn from one another.

In schools where collaboration is the exception, teachers rarely know what is going on in the classroom right next door (Heller \& Firestone, 1995; Marzano, 2003; Firestone, Schorr, \& Monfils, 2004). If teachers want to be leaders and their school community celebrates the value of teacher leadership, then the door is open to provide sustainable professional development that enhances teachers' efforts (Lieberman \& Miller, 2005). In line with this foundation, it is evident that teachers learn to lead within a school and adopt leading change from the classroom (Lieberman \& Miller, 2005) and among their peers inspire and inculcate positive Teachers' Leadership Competency (TLC).

Hence, it is essential to be aware of whether teachers' self-directed professional learning is capable of enhancing teachers' leadership competency. Having a clear vision will offer significant advantages into a positively enhanced teachers' leadership competency.

\section{Statement of the Problem}

It is hardly to believe that the professional development led by teachers was an increadible success (Lieberman, Campbell, \& Yashkina, 2017). Nonetheless, this need is not being well discussed in the context of leadership development (Mohd Majid Konting, 2012). In relation to this, the Malaysian Education Blueprint has placed great emphasis on informal leadership roles of teachers as school 
INTERNATIONAL JOURNAL OF ACADEMIC RESEARCH IN BUSINESS AND SOCIAL SCIENCES Vol. 9, No. 2, Feb, 2019, E-ISSN: 222 2-6990 (C) 2019 HRMARS

leaders (KPM, 2015), with the experienced teachers support. Hence, experienced teachers need to undertake self-directed advance professional learning and facilitate knowledge exchange for the spread and sustainability of effective and innovative practices. In other words, it requires teachers to function as change agents in transforming the schools into $21^{\text {st }}$ century schools.

In Malaysia, the need to explore effective approaches to self-directed professional learning and leadership for school improvement is highly needed and accepted. It is how experienced teachers share their self-directed professional learning, engaging colleagues in exemplary and innovative practices and bring specialized knowledge about instructional improvement to the school setting (Lieberman, Campbell, \& Yashkina, 2017; Mangin \& Stoelinga, 2008). Thus, need analysis study on the importance of teachers' self-directed professional learning and leadership in Malaysian context need to be conducted which aim to enhance teachers' leadership competencies in learning-centered schools.

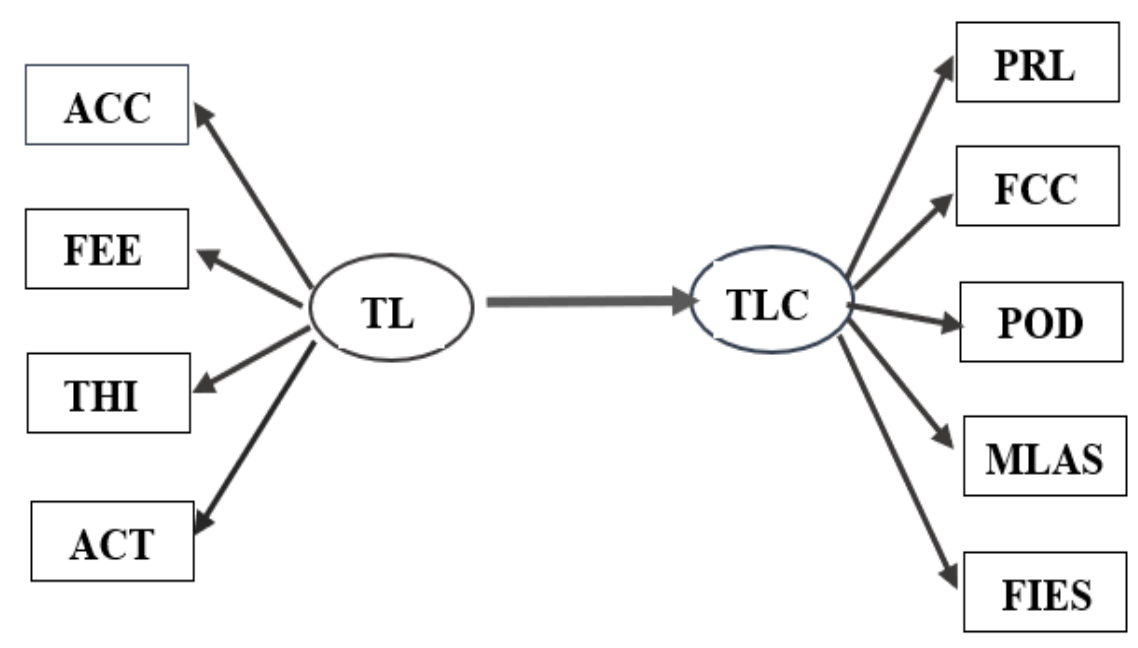

Figure 1. The Proposed Conceptual Framework of the Study

\section{Research Objectives}

The effective way to find out the solution of the above phenomenon is through research objectives (RO) as follows:

RO1. To determine whether Teacher Learning is significantly described by Action, Thinking; Feeling; and Accessing.

RO2. To determine whether Teachers' Leadership Competency Model is described by the subsequent five domains: Facilitating Improvement and Establishing Standards; Modeling Leadership Attributes and Skills; Participating in Organizational Development; Fostering a Collaborative Culture; and Performing as Referral Leader. 
INTERNATIONAL JOURNAL OF ACADEMIC RESEARCH IN BUSINESS AND SOCIAL SCIENCES

Vol. 9, No. 2, Feb, 2019, E-ISSN: 2222-6990 C 2019 HRMARS

RO3. To determine whether Teacher Learning is significantly related to Teachers' Leadership Competency. Generally, fitness of data was evaluated before statistically conducting factor analysis for TLCS.

\section{Research Questions}

Based on the purposes and objectives of the study, three research questions (RQ) were formulated to guide the study. The research questions were as follows:

RQ1. Is Teacher Learning measurement model construct-valid?

RQ1.1. Can Teacher Learning be explained by the following four factors:

Action; Thinking; Feeling; and Assessing?

RQ2. Is Teachers' Leadership Competency measurement model construct-valid?

RQ2.1. Can Teachers' Leadership Competency be explained by the following five factors: Facilitating Improvement and Establishing Standards; Modeling Leadership Attributes and Skills; Participating in Organizational Development; Fostering a Collaborative Culture; and Performing as Referral Leader?

RQ3. Is Teacher Learning significantly related to Teachers' Leadership Competency?

RQ3.1. Can Teacher Learning enhance Teachers' Leadership Competency?

\section{Research Hypotheses}

Based on the above research questions, the study derives into three research hypotheses $(H)$ to guide the study. The following were the hypotheses for RQ1 - RQ3:

RQ1. Is Teacher Learning measurement model construct-valid?

H1. Teacher Learning can be explained by the following four factors:

Action; Thinking; Feeling; and Assessing.

RQ. Is Teachers' Leadership Competency measurement model construct-valid?

H2. Teachers' Leadership Competency can be explained by the following five factors: Facilitating Improvement and Establishing Standards; Modeling Leadership Attributes and Skills; Participating in Organizational Development; Fostering a Collaborative Culture; and Performing as Referral Leader.

RQ. Is Teacher Learning significantly related to Teachers' Leadership Competency?

H3. Teacher Learning can enhance Teachers' Leadership Competency.

\section{Research Methodology}

The current study employs quantitative research in order to collect data related with the relationship between endogenous (TL) and exogenous (TLC) variables in school change initiatives through survey instrument. Survey instrument is chosen due to fast turnaround of data accumulation (Babbie, 1990; Fowler, 2009). The research design of this study is constructed based on the hypothetico-deductive method which divides the research into nine series of steps. The steps are essential in answering the three research questions (Neuman, 2006) as described previously. The series of nine steps consists of: i) Identifying the issues to be studied; ii) Reviewing the literature related to the issue; iii) Developing conceptual framework; iv) Formulating/Identifying Research Questions (RQ) and 
INTERNATIONAL JOURNAL OF ACADEMIC RESEARCH IN BUSINESS AND SOCIAL SCIENCES Vol. 9, No. 2, Feb, 2019, E-ISSN: 2222-6990 C 2019 HRMARS

Research Hypothesis (RH); v) Determining the measurement for the variables/constructs involved; vi) Pre-testing the survey instrument; vii) Pilot testing; viii) Field studying, as well as ix) Discussion on the findings. Furthermore, as depicted in Table 1, the respondents of this study are teachers from High Performing Secondary Schools in Shah Alam, Malaysia.

\begin{tabular}{|l|l|}
\hline Target Population & 1203 teachers (N=1203) \\
\hline Sampling Frame & $\begin{array}{l}301 \text { ( } \mathrm{n}=301) \text { [25\% of population] teachers from High } \\
\text { Performing Secondary Schools in Shah Alam, Malaysia }\end{array}$ \\
\hline Sampling Method & Proportionate Random Sampling \\
\hline Data Collection Method & Distribution of Survey Instrument \\
\hline
\end{tabular}

Table 1. Data Collection Procedure

\section{Data Analysis Procedure}

The actual study data will be analyzed based on two distinct statistical procedures. The statistical procedures consist of descriptive (percentage data) and multivariate analysis with Structural Equation Modelling (SEM). As preparation for main data analysis, several (eight) procedures will be employed. The series of eight procedures consists of: i) Entering the raw data into simple data entry file in SPSS; ii) Screening data for the treatment of missing data, assumptions of outliers, normality, linearity, multicollinearity, as well as the homoscedasticity of the data; iii) Data editing; iv) Data coding; v) Data screening; vi) Linearity Test; vii) Multicollinearity Test; and viii) Homoscedasticity (Constant Variance) of Errors Test. Next, the structural model which represents the theory with a set of structural equations will be assessed at second stage linking latent variables to each other (Byrne, 2001; Kaplan, 2000; Kline, 2005) by utilizing SEM. According to Hair et al. (2006), similar fit statistics for measurement and structural models indicate an acceptable structural model. Once the measurement models achieved the good-fit of the full-fledged model, the outcome will be assessed and reported based on research questions 3 as follows:

RQ3. Is Teacher Learning significantly related to Teachers' Leadership Competency?

RQ3.1 Can Teacher Learning enhance Teachers' Leadership Competency?

\section{Conclusion}

In a nutshell, this study accumulates key dimensions for teachers' self-directed professional learning and proposes a framework to determine the influence of these dimensions towards teachers' leadership competency. This study intends to uncover the influence of teachers' self-directed professional learning in enhancing teachers' leadership competency. 


\section{Theoretical and Contextual Contribution of the Research}

Firstly, the findings of the study provide input to enhance Teachers' Leadership Competency (TLC) that promotes the inclusion of leadership values, skills, and knowledge, and formally into Teacher Learning (TL).

Secondly, to date, Teacher Learning (TL) enhances Teachers' Leadership Competency Model (TLCM) towards improved instructional practices beyond individual classrooms (CSTP, 2009). This would enable better understanding which specified TLCM in various school improvement initiatives needed in Malaysian schools (KPM, 2014). In other words, this model would have significant far-reaching implications for leadership for learning among teachers and thus maximizing leadership impact.

Thirdly, TL supports the development of TLCM (Kho, Hamidah, Yusof \& Syed Ismail Syed Mohamad, 2015a) which is tailored for effective professional development in various disciplines for teachers (KPM, 2014). As teacher leadership is the process to convince others to use a new approach while enhancing leadership skills, the effectual approach to develop teacher leadership is through TLCM, and subsequently creating ways and conditions which nurture and sustain the excellence in TL.

Fourthly, the essential TLCM was constructed based on five domains, as derived from leadership competencies models, which had been amended to suit local contexts. Precisely, the synthesized underlying theoretical perspective of the model would add to the value of leadership development culture. It would also enhance practitioners' leadership values, skills, and knowledge, and provides direction as useful feedback in the implementation of leadership practices and the development of professional learning communities in Malaysian secondary schools.

Finally, the Teachers' Leadership Competency Scale (TLCS) is a promising and a welcoming tool for both practitioners and scholars as it is rooted in a sound review of the literature. Simply stated, this research-based application tool would promote to more evidence-based assessment in the development of local-based leadership competency.

\section{Acknowledgement}

The authors would like to acknowledge Sultan Idris Education University for funding this study through the University Research Grant (GPU); code: 2017-0317-107-01.

\section{Corresponding Author}

Dr. Fanny Kho Chee Yuet, Senior Lecturer, Faculty of Management and Economics, Sultan Idris Education University, Tanjong Malim, Perak, Malaysia.

Email: fannykcy@fpe.upsi.edu.my

\section{References}

Babbie, E. (1990). Survey research methods (2nd ed). Belmont, CA: Wadsworth.

Byrne, B.M. (2001). Structural Equation Modelling with Amos: Basic concepts, applications, and programming. Mahwah, NJ: Erlbaum.

Crowther, F., Kaagan, S.S., Ferguson, M., \& Hann, L. (2002a). Developing Teacher Leaders: How Teacher Leadership Enhances School Success. California: Sage Publications. 
INTERNATIONAL JOURNAL OF ACADEMIC RESEARCH IN BUSINESS AND SOCIAL SCIENCES

Vol. 9, No. 2, Feb, 2019, E-ISSN: $2222-6990$ ๑ 2019 HRMARS

Crowther, F., Hann, L. \& Andrews, D. (2002b). Rethinking the Role of the School Principal: Successful School Improvement in the Postindustrial Era. Australia: The Practicing Administrator.

Centre for Strengthening the Teaching Profession (2009). Teacher Leadership Skills Framework. Available at http://www.cstp-wa.org

Darling-Hammond, L. (1999). Educating teachers: The academy's greatest failure or its most important future? Academe, 85(1), 26-33.

DuFour, R., \& Fullan, M. (2013). Cultures built to last: Making PLCs systemic. Bloomington, IN: Solution Tree.

Firestone, W. A., Schorr, R. Y., \& Monfils, L. (2004). The ambiguity of teaching to the test. Mahwah, NJ: Lawrence Erlbaum.

Fowler, F. J. (2009). Survey Research Methods (4th ed.). Thousand Oaks, CA: Sage Publications.

Hair, J.F., Anderson, R.E., Tatham, R.L., \& Black, W.C. (2006). Multivariate data analysis (5th ed.). New Jersey: Prentice Hall.

Heller, M. \& Firestone, W. A. (1995). Who's in charge here? Sources of leadership for change in eight schools. The Elementary School Journal, 96 (1), 65-86.

Hill, K. G., \& Amabile, T. M. (1993). A social psychological perspective on creativity: Intrinsic motivation and creativity in the classroom and workplace. In S. G. Isaksen, M. C. Murdock, R. L. Firestien, \& D. J. Treffinger (Eds.), Understanding and recognizing creativity: The emergence of a discipline (pp. 400-432). Norwood, NJ: Ablex.

Kaplan, D. (2000). Structural Equation Modelling: Foundations and extensions. London: Sage.

Kementerian Pendidikan Malaysia (2012). Preliminary Report: Malaysia Education Blueprint 20132025. Kuala Lumpur: Kementerian Pendidikan Malaysia.

Kementerian Pendidikan Malaysia (2014). Institut Pendidikan Guru Malaysia. Kuala Lumpur: Kementerian Pendidikan Malaysia.

Kementerian Pendidikan Malaysia (2015). Surat Pekeliling Ikhtisas Kementerian Pendidikan Malaysia Bilangan 7 Tahun 2015: Pelaksanaan Sekolah Berprestasi Tinggi. Kuala Lumpur: Kementerian Pendidikan Malaysia.

Kho, C.Y. Fanny, Hamidah Yusof \& Syed Ismail Syed Mohamad (2015a). A Confirmatory Factor Analysis of the Niche-Malaysian Teacher Leadership Competency Instrument (NMTLCI). Australian Journal of Basic and Applied Science 9(25), 125-133.

Kho, C.Y. Fanny, Hamidah Yusof \& Syed Ismail Syed Mohamad (2015c). The power of leadership for learning: Developing Niche-Malaysian Teacher Leadership Competency Model. Proceedings of the International Conference on Accounting Studies. Langkawi, Malaysia.

Kho, C.Y. Fanny, Hamidah Yusof \& Syed Ismail Syed Mohamad (2016). Development and Validation of the Teacher Leadership Competency Scale. Malaysian Journal of Learning and Instruction, 13(2), 43-69.

Kline, R.B. (2005). Principles and practice of Structural Equation Modelling (2nd ed.). New York, NY: Guilford.

Lieberman, A., \& Miller, L. (2005). Teachers as leaders' essays. The Educational Forum, 69(2), 151162.

Lieberman, A., Campbell, C., \& Yashkina, A. (2017). Teacher learning and leadership: Of, by, and for teachers. London, England: Routledge. 
Mangin, M.M. \& Stoelinga, S.R. (2008). Effective teacher leadership. New York: Teachers College Press.

Marcus, S. H., \& Pringle, A. (1995). What Competencies Are Needed in a Changing Environment? The Human Resources Professional, 8(3), 19-24.

Marzano, R. J. (2003). What works in schools. Translating research into action. Alexandria, VA: Association for Supervision and Curriculum Development (ASCD).

Mohd. Majid Konting (2012). Leadership Development for Sustainability of E-Learning. Procedia Social and Behavioral Sciences 67, 312 - 321.

Timperly, H., Wilson, A., Barrar, H., \& Fung, I. (2007). Teacher professional learning and development: Best evidence synthesis iteration [BES]. Retrieved from OECD website: http://www.oecd.org/edu/school/48727127.pdf.

Yamazaki, Y., \& Kayes, D.C. (2004). An experiential approach to cross-cultural learning: a review and integration of success factors in expatriate adaptation. Academy of Management Learning Education, 3(1), 4-15. 